\title{
CONCEPTUALIZING LITERACY IN AAC: SOME REFLECTIONS
}

\author{
Magnus Magnusson, Lia Kalinnikova-Magnusson \\ Stockholm University, Gävle University, Sweden
}

\begin{abstract}
Literacy is a concept, which almost has taken over and included concepts like reading, writing and inter human social communication in general. However, it has only recently been integrated into the AAC-fields connected to social work, special education and assistive technologies. This paper focuses on some key-questions regarding AAC and literacy, mentioning that the holistic approach of AAC in combination with a general linguistic theory as the one by Charles Peirce, creates a more whole or holistic perspective for thinking and looking for answers on these questions. The social model created by Uri Bronfenbrenner is also very applicable. Even though a holistic approach demands openness on the behalf of the teacher or interventionist as well as of the user her/himself, it is important to remember the need for good methods and methodology, based upon good practical evidence with the common target to acquire literacy.

KEY WORDS: communication, alternative and augmentative communication (AAC), literacy, reading, writing.
\end{abstract}

\begin{abstract}
Anotacija
Raštingumas bendraja prasme suprantamas kaip konceptas, apimantis skaitymą, rašymą ir tarpasmeninị socialinị bendravimą. Neseniai jis integruotas ị augmentinès ir alternatyviosios komunikacijos (AAK) sritis, susietas su socialiniu darbu, specialiaja pedagogika ir pagalbinèmis technologijomis. Šiame straipsnyje analizuojami esminiai augmentinès ir alternatyviosios komunikacijos bei raštingumo klausimai, aptariama augmentinès ir alternatyviosios komunikacijos holistinè perspektyva, remiantis bendraja lingvistikos teorija. Pateikiamas Uri Bronfenbrenner socialinis modelis.

PAGRINDINIAI ŽODŽIAI: komunikacija, augmentinè ir alternatyvioji komunikacija (AAK), raštingumas, skaitymas, rašymas.
\end{abstract}

DOI: http://dx.doi.org/10.15181/tbb.v68i4.953

\section{Introduction}

In the relatively new area of AAC there are many pertinent and valid questions to ask and research to make. One central idea is the fact that all good investigations and data collections should be evidence-based or connected since in the field it is difficult to find large populations available for systematic research, instead lots of "cases" and individual need. This is true as well about needs connected to social communication and literacy in the AAC field. This paper will make a few reflections upon the nature of literacy as a special concept in the AAC-field. We will however not separate between the needs of children or adults but focus more on similarities between the age-groups more than differences even though questions of literacy most often are related to the field of children and young people. 


\section{Background}

Human communication and interaction could be described in a simple model as consisting of sensory channels and motor structures working together against a background of basic cognitive abilities - a three-part model. It could be described in almost dialectic interactions:

In the Auditive channel (Hearing and Talking) we are using sounds and most often speech through our motor system.

In the Visual channel (Seeing and Showing) we are using body movements and the motor management of symbols.

In the other sensory channels (e.g. tactile) the symbolic content often is taken as sub-ordered to the visual and auditive channels.

When we interact with each other we then use sensorimotor abilities where a general cognitive ability - the third part of the model - makes it possible for us to use symbols to create and to understand messages between ourselves. A fourth part to add to the model could be the social context, the simple fact that it is never enough to communicate with yourself. During the last decade, some researchers and developers, notably Sarah Blackstone (Blackstone \& Hunt Berg, 2003), have reminded us that we need to remember the partners and the context when developing communication models for AAC-users and their partners. The social part is important to make us remember that all of us belong to social contexts and that communication and literacy is the main elements or factors to make us part of the social context.

...ability to identify, understand, interpret, create, communicate and compute, using printed and written materials associated with varying contexts. Literacy involves a continuum of learning in enabling individuals to achieve their goals, to develop their knowledge and potential, and to participate fully in their community and wider society (Unesco, 2004).

In an oversimplified hierarchical model of communicative ability and development we tend however to look upon speech as more basic and primary than writing and text. When we work with AAC-intervention, we therefore have a tendency to see communication as a variation of the fundamentals, that is of speech, forgetting the other parts even though speech can be represented visually and become part of the visual channel. In other words, we tend to forget that interpersonal communication is more holistic and that speech is just one part of a more complex pattern. In other words, to be able to fully understand AAC we need to develop a more holistic understanding of communication where the symbol function and 
its representation is central (Magnusson, 2009). There the concept literacy will be central in this understanding.

\section{What is literacy}

...from viewing literacy as a simple process of acquiring basic cognitive skills, to using these skills in ways that contribute to socio-economic development, to developing the capacity for social awareness and critical reflection as a basis for personal and social change (Unesco-report, 2006).

...Active transformation of text (Hiebert, 1991, p. 2).

In modern society the ability to read and write is taken for granted. Our educational systems all over the world train children from a very early age to manage reading and writing texts in a way that makes the three words reading, writing \& text almost obsolete or rather insufficient even though our everyday understanding of the words is very clear - "everybody knows what it means to read and write, and that you have to know how to do it". However, to really understand the deeper meaning of the concepts, we need a more general term to include the basic ability to manage symbols in the environment in general. The concept text is no longer equivalent to a page of a longer continuity in a concrete medium like a book or a journal. Instead, text is also traffic signals in a city, advertisement signals, text lines and squares on the TV-screen, SMS-messages on a mobile phone etc etc. The question to ask and to remember is that the ability to read and write also includes WHAT to read and write and of course the concept of understanding, meaning that reading and writing has a cognitive element which is as important as a possible more technical element like the concept decoding for instance. This becomes extra important when we consider the frequence of cognitive or intellectual disabilities in combination with reading and writing difficulties that are being highlighted more and more in modern society.

A suitable framework to start from to define the basics of an enlargened textconcept could be the three concepts icon, index and symbol as defined by philosopher Charles Peirce: Icons, indices, and symbols. Every sign refers either (icon) through similarity to its object, or (index) through factual connection to its object, or (symbol) through interpretive habit or norm of reference to its object (Wikipedia, 2014). According to this, text is built up by signs in the terminology of Peirce, and if text is built up by signs then the signs can be seen as similarity (icon), content (index) and interpretation (symbol), which means in practice that when we 
read any type of text we manage signs as a tool to understand or bring meaning to the text.

Since reading a text also means relating to someone's intention with the text, it also means "listening" in a general sense. Behind the text there is someone meaning something with the text, a message which might or might not be directed specifically to the single reader of the text. However, by reading a text, the reader also creates an intention towards the text, to bring meaning to the text. This is a direct parallel to the process of talking and listening where the "signs" are auditive. Listening (and reading) is not just receiving but bringing your own interpretation, verification and acceptance to the message.

Another conclusion that could be made, although slightly controversial, out of Peirce's Semiotic theory on signs is that in principle it is no difference between learning to read (and write) than to speak and to understand spoken language. The different parts of the body mature in different ways so that it could be argued that the human body is not ready to manage the tools necessary to operate graphical signs as early as to manage the motor parts of the body necessary for speech sounds. In principle decoding visually and auditively should be correlated to each other and there are researchers who have made successful research regarding early reading/writing teaching of siblings, for instance professor Ragnhild Söderbergh (1997).

Today our different media and the connected forms of communication have brought the visual (written) text-based forms of communication closer to the auditive or spoken ones as well as to the tactile forms, a fact that has been known to the AAC-community for a long time. This means that the holistic approach to communication is more accepted today and also the realization that text as a central concept as well as the text-related concepts reading and writing have to be considered in-depth when we work with AAC since text and the so called written language often takes over the role of the spoken language, especially for persons using graphical symbol language. Since the formal structures of written and spoken languages are considered as quite different in any linguistic theory, especially if we look at the extremes of the two different forms of language, it is still important to be able to differentiate between the two forms. In other words, even if we (should) know how to talk today, we also (should) know how to read and write. The word "should" denotes a social content, that is, a demand from the world around us to adapt.

There are rules for all sorts of communication and the basic rule is to create forms of communication which will be understandable to other people, to make us a part of the general society, a process of inclusion where our demands also have to be considered. This of course includes literacy since it is a form of communi- 
cation. Here once again we have to remind ourselves of the added needs and considerations that come from the fact that so many persons of different ages today are discovered to have reading and writing problems, even escalating to the clinical term Dyslexia.

\section{Basic characteristics of AAC}

Connecting to the discussion above, we have to stress that AAC always has taken a holistic approach to communication, aiming to analyze the total communicative potential in individuals and out of this and the awareness of the community, develop optimal communicative structures. Already Silverman (1980) stated that "from the communications orientation, on the other hand, the ultimate goal of therapy would be developing the ability to communicate to a level adequate to meet communication needs". This can include aided as well as unaided communication, use of so called advanced technology, body language, sign(ed) language etc. We will not waste time and space here to describe AAC more in detail since detailed knowledge of AAC is expected to be known by the readers. Open attitudes in combination with awareness of the basics of communication and language as well as social aspects of communication are central, from the users themselves as from family and professionals.

Since the user structures of language often become very individualized in AAC communication, it is important to consider the social and contextual aspect of communication, that is, that everyday communication as well as formal written or spoken communication follows certain common social rules. It is of course good that an individual can get an individual tool or method for communicating with the closest persons as happens initially in most cases of AAC-application. However, as we all know and which has been formulated so well and early by Bronfenbrenner (1979) - all of us exist and communicate on different levels like Mikro, Meso and Makro etc and there are certain demands and rules connected with every level or every different social context that we may move between and we all need to learn divers patterns of communication to be able to cover as large a communicative arena as we want. One problem which may attack people who use AAC is that they become limited in their social networking, a problem of inclusion as well as democracy.

AAC has a strong and dynamic history during its three decades of existence of being very much individually oriented. AAC-user, is a concept which is a bit difficult to use, but for lack of better is used generally in AAC-literature as a common term to describe an individual who communicates by using different methods of $\mathrm{AAC}$ and the individual and her or his special need(s) have always been in focus in 
the AAC-field. In research as well as methodological literature, it has always been difficult to find larger groups with special common needs definable as AAC causes or needs. In certain sources, the needs are connected to certain clinical diagnoses, in other, sources are connected to certain methods and functions. This wide approach to categorize and understand the field and the needs of the users, is a very good representation about the wide area of needs that the field actually covers and also the approaches of all the groups working actively in the field of AAC. The field is in another words a multi-professional and conceptual field where professionals are looking for common ground and users are looking for general solutions and communication models for themselves.

The field is in another words still looking for its identity and one way of doing it is by using evidence-based practice to show bottoms-up what really works well for different groups and individuals and then hopefully AAC is slowly creating its own arena. And today probably the strongest trends in the field is to investigate the aspects of inclusion (social aspects) and the aspects of literacy, that is, how to connect the often individualized AAC-methods to a more general way of communicating. By this, evidence-based approach is connected to and based upon a general accepted knowledge about the central parts of the AAC-field.

\section{Literacy and AAC}

There exists a lot of mainly methodological literature on AAC and literacy at the moment as can be seen from the examples in the reference list. Research investigations are fewer and we could say that we exist in a period of common data-collecting and free comparison of data against a background awareness that there is a need for action, theory and understanding. When I make a quick literature survey in the database ERIC I find 30 references connected to the search AAC \& Literacy with mostly individual studies reported (Lacey, 2000). One study is of special interest, trying to define the central need in question (Light \& McNaughton, 2012). The authors identify two main problems to be faced by future researchers: " 1 . How to improve the design of AAC apps/technologies so as to better meet the breadth of communication needs for the diverse population. 2. Ensuring the effective translation of these evidence-based AAC interventions to the everyday lives of children with Complex Communication Needs so that the "possible" becomes the "probable." Even though this article focusses on children it is clear that they recognize the need to meet the complexities and broad variations of the AAC-field and its users and also to make concrete the visions and ideas emanating from future researchers. In this complexity it also has to be added that $\mathrm{AAC}$ also focusses on the needs of 
adults and that lifelong learning is part of the general holistic complexity. In their article they recognize literacy to be the concept which describes the possibilities for the single AAC-user to become an active member of society.

Let us now bring together the fragments of this paper so far. We recognize the general complexity of the AAC-field and the need for a holistic approach where the needs of the individual are in focus, or, to quote Bronfenbrenner again, a micro perspective (ibid, 1979). On the other hand, we need approaches on the meso and macro perspective as well where the social component is in center, that is, the possibility to communicate with more people and in more contexts and situations. We also need to remember the needs from different disabilities. If you have cognitive needs and for instance reading and writing problems to add to the general AACneeds this of course will have to be remembered when focusing on literacy. Let us then apply all of these considerations to the question of literacy, which we also know as a holistic field.

If we consider the target person to be someone who is in need of a basic communication method when we start working together, in the beginning firstly we have to consider the social network and its structure (Blackstone \&Hunt Berg, 2003), secondly the context and thirdly the type of method to use. This beginning has to consider the needs first of all on the micro level. How do we as professionals establish a training program in cooperation with the user and the family and possible practitioners and in which context? The first answer to this question is to establish a strong network where the participants work out a sort of contract between each other and see to it that they are well aware of each other's roles, in mutual cooperation. To this network we must foresee the need to establish contacts with more experts outside the inner network, maybe in more of diagnostic and supervision roles. This would probably be the case when there would be a need for special consulting, e.g. around modelling literacy competence.

Text and symbols have always been very central in AAC-communication and for large groups of AAC-users text has become the central part of communication. This means that some of the first trials with text-based distance communication systems were used for and with persons with communication disabilities, for instance hearing problems (Cerf, 1976) or AAC-users (Magnusson, 2001). The central importance of text in AAC poses some interesting questions for further research into what happens with communication (=utterances) which have the same status as spoken utterances but are produced in text and therefore remains available after being produced? What is really the effect of the difference between spoken and written language (Ong, 1990)?

Secondly we have to consider the context where we in general talk about four possible contexts: home; school; clinic; work. 
There is the fifth environment not often remembered which often is mixed up with home and that is the place of a friend or a neighbor, that is, a home environment but not one's own. There are of course different possibilities and demands in all the environments but in general one could see home and neighbor as the places where you freely practice what you learn and train in the others. In the different environments it has to be established a working relation between duty and freedom of expression. Even though we formally can differentiate between those five environments theoretically, in practice they ineract and mingle with each other so that a general communication arena for a (young) AAC-user can be quite multi-faceted and simply confusing (Narajan, 2010).

Finally we talk about the methodology to be used. The basic word when talking about methods and methodology is structure (Light \& Binger, 1998). Planning is of outmost importance and according to a good combination of scientific knowledge, professional practical knowledge and empathy. The empathy can generally be taken for granted but regarding the other two components it can be more problematic, mostly because the multiple background area of AAC occasionally can cause competitive interests and results, especially regarding the professional experience. Mutual respect between professionals and others within the network already mentioned is of course necessary. Another important aspect is the necessity to think about the pragmatics of speech and interaction, another way to describe a social aspect of communication (Todman, Alm \& File, 1999).

Regarding literacy, it is important to remember the theory of reading acquirement that states that phonological awareness is essential for learning to read. During the early child development, phonology and phonological awareness is developed through talking and connecting sounds to signs which is difficult if you are non-speaking or have severe communication problems. Likewise, perception and the ability to follow the figure of a letter might cause problems in reading or sign acquirement. However, many adults with severe communication problems and non-speaking have learnt to read and write using letters.

Problems related to the cognitive ability can be many, from intellectual dysfunction or disability to decoding problems or the problems contained in the word Dyslexia. Also, it might be interesting to investigate whether neuropsychological phenomena are causing the need of special reading and writing methodology as for example in connection with Autism-related phenomena where a general communication variation can be seen. However, several wellknown researchers and intellectuals with autism have mastered reading and writing without an problem at all so this raises a final very interesting problem worth investigating closer whether reading and writing ability automatically can be seen as parts of communication abilities without reservations. The same also goes for speech. 


\section{Conclusion}

This short and fragmentary paper has tried to pinpoint on a clear but wide problem to consider in the field of AAC - literacy and what it implies. There are no definite answers to find, just some reflections and considerations, aiming to bring together our different approaches, competencies and experiences despite what field of interest we might come from, be it professional or private. We have a lot to give each other and we must not forget to add the ultimate experts on AAC to our target group, the "users" themselves. To make the possible become the probable is a well-worth target for our intentions regarding AAC and literacy.

Received 20141010

Approved for publishing 20141222

\section{References}

101 ideas for literacy and $A A C$. Website: http://talksense.weebly.com/literacy-and-aac.html

AAC Balanced Literacy. Website: http://aac-balancedliteracy.wikispaces.com/

Blackstone, S. W., Hunt Berg, M. (2003). Social Networks - A Communication Inventory for Individuals with Complex Communication Needs and their Communication Partners. Monterey, California: Augmentative Communication Inc.

Bronfenbrenner, U. (1979). The Ecology of Human Development. Experiments by Nature and Design. Cambridge, Mass: Harvard University Press.

Cerf, V. (1976). The Electronic Mailbox: A New Communication Tool for the Hearing Impaired Am Annals of the Deaf 123: 768-772.

Everyone Communicates: Literacy and AAC. Website: http://www.everyonecommunicates.org/resources/literacy. html

Hiebert, E. H. (1991). Introduction. In: E. H. Hiebert (ed.). Literacy for a diverse society: Perspectives, practices, and policies. New York: Teachers College Press, p. 1-6.

Lacey, P. (2000). Literacy and Pupils with Profound and Multiple Learning Disabilities. Birmingham, International Special education Congress.

Lanir, L. (2012). Website: http://www.decodedscience.com/charles-sanders-peirce-symbolic-iconic-and-indexical-signs/23013

Light, J., Binger, C. (1998). Building Communicative Competence with Individuls who Use Augmentative and Alternative Communication. Baltimore: Paul H. Brookes Publishing Co.

Light, J., McNaughton, D. (2012). Supporting the Communication, Language, and Literacy Development of Children with Complex Communication Needs: State of the Science and Future Research Priorities. Assistive Technology 24: 34-44.

Light, J., McNaughton, D. (2012). Supporting the Communication, Language and Literacy Development of Children with Complex Language Needs; State of the Science and Future Research Priorities. Assistive Technology 24: $34-44$.

Literacy and AAC. Website: https://www.msu.edu/ rbailey/literacy_and_AAC.html

Magnusson, M. (2001). Life in Language - Language in Life. Karlstad: Karlstad University.

Magnusson, M. (2009). Conceptions of AAC. In: M. Magnusson, L. Kalinnikova (eds.). TOUCH, EEAAC-conference. Archangelsk.

Narajan, S. (2010). Disentangling the Social Threads within a Communicative Environment. European Journal of Special Needs Education 25(3): 253-267.

Ong, W. J. (1986; 1990). Oral and Written Culture. Göteborg: Anthropos.

Silverman, F. H. (1980). Communication for the Speechless. Marquette University, New York: Prentice Hall. 
Söderberg, R. (1997). Tal och skrift i samspel i den tidiga språkutvecklingen. Stockholm, Liber, I Ragnhild Söderbergh (Red): Från Joller till läsning och skrivning, sid 264-277.

Sturm, J. M., Clendon, S. A. (2004). Augmentative and Alternative Communication. Topics in Language Disorders 24(1): 76.

The Plurality of Literacy and its implications for Policies and Programs. (2004). UNESCO Education Sector Position Paper 13.

Todman, J., Alm, N., File, P. (1999). Modelling Pragmatics in AAC. In: F. T. Loncke, \& al (eds.). Augmentative and Alternative Communication - New Directions in Research and Practice. London: Whurr Publishers, p. 84-91.

Website: http://en.wikipedia.org/wiki/Semiotic_elements_and_classes_of_signs. (2014).

Website: http://www.unesco.org/education/GMR2006/full/chapt6_eng.pdf. (2006).

Wilkins, J., Ratajczak, A. (2009). Developing Students' Literacy Sklils Using High Tech Speech Generating Augmentative and Alternative Communication Devices. Intervention in School and Clinic 44(3): 167-172. 